\title{
ANALISA TINGKAT PENGETAHUAN IBU TENTANG IVA DENGAN UPAYA PENCEGAHAN CA CERVIX DI KLINIK NAMIRA KOTA SEMARANG
}

\author{
Widyah Setiyowati ${ }^{1)}$, Titik Kurniawati ${ }^{2)}$, Desi Rosalina ${ }^{3)}$ \\ ${ }^{1}$ Prodi DIII Kebidanan STIKes Guna Bangsa \\ ${ }^{2}$ Prodi S1 Kebidanan STIKes Guna Bangsa \\ ${ }^{3}$ Prodi DIII Kebidanan Universitas STEKOM \\ Email: widyahsetiyowati@gmail.com
}

\begin{abstract}
ABSTRAK
Kanker leher rahim atau disebut juga kanker serviks adalah sejenis kanker yang 99,7\% disebabkan oleh human papilloma virus (HPV) onkogenik, yang menyerang leher rahim. Kelompok berisiko untuk terjadinya kanker serviks adalah wanita di atas usia 30 tahun yang memiliki banyak anak dan dengan perilaku menjaga kesehatan reproduksi yang masih kurang. Kebiasaan gonta ganti pasangan seksual merupakan salah satu faktor utama penularan virus HPV penyebab kanker serviks ini terjadi. Tujuan penelitian ini adalah untuk menganalisa tingkat pengetahuan ibu tentang IVA dengan upaya pencegahan Ca cervix. Jenis penelitian ini adalah descriptive analitik dengan rancangan cross sectional, sampel dalam penelitian ini adalah 30 orang, diambil dengan tehnik total sampling.pengujian hipotesis menggunakan chi square. Sebagian besar responden memiliki tingkat pengetahuan kurang sebesar 17 (57\%) responden dan memiliki upaya pencegahan yang kurang atau tidak pernah melakukan upaya pencegahan sebesar $22(73 \%)$ responden. Ada hubungan yang significan antara tingkat pengetahuan tentang IVA dan upaya pencegahan ca cervix, Dengan hasil p value sebesar $0,03<\mathrm{a}(0,05)$. Saran diberikan kepada masyarakat khususnya wanita PUS untuk meningkatkan pengetahuan dan upaya untuk pencegahan Ca cervix
\end{abstract}

Kata kunci: Tingkat Pengetahuan, Upaya Pencegahan

\begin{abstract}
According to Law No. 10 of 1992, family planning is an effort to increase awareness and participation of the community through maturing the age of marriage, birth control, fostering family resilience, increasing family welfare to create a small, happy and prosperous family. Family planning users in Jatijajar Village, RW 01, Bergas District, Semarang Regency, as many as 148 people, consisting of 8 people for IUD, 0 people for MOP, 2 people for MOW, 1 implant, 38 people for 1 month injection, 89 people for 3 months injection, 4 pills, 5 condoms. soul. The purpose of this study was to determine the relationship between the duration of the use of injectable contraception for 3 months with the incidence of weight gain in family planning acceptors. This type of research is a survey using a correlation research design. The population in this study were 89 mothers who used 3-month injections. The number of samples is 47 respondents with simple random sampling technique. Testing the hypothesis using the chi square test. The results of this study indicate that most of the respondents experienced weight gain of $35(74.5 \%)$ and most of the respondents had used injectable contraception for 3 months 1 year, namely $38 n$ (80.9\%). Based on the results of statistical tests using Chi Square calculations with $=0.05$, the value of is 0.014, so there is a relationship between length of use and weight gain. Suggestions given to the community, especially mothers, should actively seek information from health workers regarding contraceptives to be used in order to know the side effects of contraception and how to overcome them.
\end{abstract}

Keywords: Level of Knowledge, Prevention Efforts

\section{PENDAHULUAN}

Laporan Global Burden Cancer, Internasional Agency for Recearch on Cancer (IARC) menunjukkan bahwa angka kematian kanker serviks di Indonesia adalah 8,2 kematian per 100.000 penduduk. Penyakit kanker serviks merupakan penyakit kanker dengan prevalensi tertinggi di Indonesia yaitu sebesar 0,8\% (Mulyati, 2015). 
Provinsi Jawa Tengah merupakan provinsi yang memiliki estimasi jumlah penderita kanker serviks terbanyak setelah Jawa Timur yaitu sebesar 19.734 kasus (Mulyati, 2015)

Pada tahun 2013, Kota Semarang merupakan wilayah dengan kasus kanker serviks tertinggi di Provisi Jawa Tengah yakni 529 kasus. Meskipun jumlah menurun pada tahun 2014 dan 2015 menjadi 353 kasus dan 310 kasus, namun terdapat peningkatan kasus kanker leher Rahim pada tahun 2016 menjadi 361 kasus (Dinkes Kota Semarang, 2018)

Berdasarkan data rutin Subdit Kanker Direktorat Penyakit Tidak Menular, Direktorat Jenderal Pengendalian Penyakit dan Penyehatan Lingkungan, Kementerian Kesehatan RI, sampai dengan tahun 2016, program deteksi dini kanker serviks dan kanker payudara baru di selenggarakan pada 717 Puskesmas dari total 9.422 puskesmas di 32 Provinsi. Dengan demikian, dapat dilihat bahwa Puskesmas yang memiliki program deteksi dini masih sangat sedikit atau sekitar7,6 \% (Kementrian RI, 2017)

Disisi lain kesadaran dan pengetahuan masyarakat tentang kanker termasuk faktorfaktor risiko dan upaya pencegahannya masih kurang. Padahal 90-95 \% faktor risiko terkena kanker berhubungan dengan perilaku dan lingkungan. Karena itu perlu ada suatu gerakan bersama, menyeluruh dan berkesinambungan untuk meningkatkan kepedulian masyarakat terhadap kanker terutama kanker serviks. Insiden kanker serviks sebenarnya dapat ditekan dengan melakukan upaya pencegahan primer seperti meningkatkan atau intensifikasi kegiatan penyuluhan kepada masyarakat untuk menjalankan pola hidup sehat, menghindari faktor risiko terkena kanker, melakukan immunisasi dengan vaksin HPV dan diikuti dengan deteksi dini kanker serviks tersebut melalui pemeriksaan pap smear atau IVA (inspeksi visual dengan menggunakan asam acetat), (Desby, Hardians 2018).

Skrining Kanker Leher Rahim yang dilakukan Puskesmas biasanya skrining dengan test IVA (Inspeksi Visual Asma Asetat). Sampai tahun 2017, terdapat 1.682 provider deteksi dini kanker leher Rahim dan kanker payudara di Indonesia dengan estimasi jumlah kanker serviks sebanyak 98.692 kasus. Jawa Tengah mempunyai estimasi jumlah kasus kanker serviks yaitu 19.734 dan jumlah trainer 21 orang (Kemenkes Kesehatan RI, 2018)

Saat ini cakupan "screening" deteksi dini kanker serviks di Indonesia melalui pap smear dan IVA masih sangat rendah (sekitar $5 \%$ ), padahal cakupan "screening" yang efektif dalam menurunkan angka kesakitan dan angka kematian karena kanker serviks adalah $85 \%$ (Desby, Hardians 2018).

Alasan seorang wanita tidak menjalani deteksi dini kanker leher Rahim yaitu karena ketidaktahuan, rasa malu, rasa takut dan factor biaya. Hal ini umumnya disebabkan oleh rendahnya tingkat pengetahuan dan pendidikan penduduk Indonesia, khususnya kaum wanita. Pengetahuan atau kognitif merupakan domain yang sangat penting untuk terbentuknya tindakan seseorang (Maharsie, 2012)

Tujuan penelitian ini adalah untuk menganalisa tingkat pengetahuan ibu tentang IVA dengan upaya pencegahan $\mathrm{Ca}$ cervix di Klinik Namira Kota Semarang.

\section{METODE}

Menurut sifat dasar, penelitian ini termasuk jenis penelitian deskriptif analitik, menggunakan rancangan cross sectional (belah lintang) yaitu rancangan penelitian yang dalam melakukan pengukuruan variable independen yaitu tingkat pegetahuan tentang IVA dan variable dependen yaitu upaya pencegahan $\mathrm{Ca}$ cervix dilakukan dalam periode yang sama (Hidayat, 2007).

Populasi dalam penelitian ini adalah semua wanita pasangan usia subur di Klinik Namira sejumlah 30 orang. Sampel menggunakan tehnik total sampling sehingga sampel dalam penelitian ini sejumlah 30 orang. Jenis data pada penelitian ini adalah data primer dan sekuder. Data primer didapatkan dengan menggunakan kuesioner kepada wanita usia subur. Analisa data terdiri atas analisa univariat untuk mendiskripsikan karakteristik tiap variable dan analisis bivariate menggunakan Chi-square

Hipotesa dalam penelitian ini jika nilai $\mathrm{p}<0,05$ maka dinyatakan ada hubungan bermakna antara tingkat pengetahuan tentang IVA dengan upaya pencegahan Ca cervix

\section{HASIL}


A. Karakteristik Responden

1. Umur

Tabel 1

\begin{tabular}{ccc}
\hline Umur & Jumlah & $\%$ \\
\hline$>25$ & 20 & 66,6 \\
$>35$ & 8 & 26,6 \\
$>45$ & 2 & 6,6 \\
\hline Jumlah & 30 & 100 \\
\hline
\end{tabular}

Berdasarkan data diatas diperoleh hasil bahwa responden kategori umur paling banyak yaitu umur $>25$ tahun sebanyak 20 responden
$(66,6 \%)$ dan paling sedikit umur $>45$ tahun sebanyak 2 responden $(6,6 \%)$.

2. Pendidikan

Tabel 2

\begin{tabular}{ccc}
\hline Pendidikan & Jumlah & $\%$ \\
\hline Tidak Sekolah & 7 & 23 \\
SD & 3 & 10 \\
SMP & 8 & 27 \\
SMA & 9 & 30 \\
S1 & 3 & 10 \\
\hline Total & 30 & 100 \\
\hline
\end{tabular}

Berdasarkan table diperoleh hasil bahwa responden kategori pendidikan paling banyak SMA sebanyak 9 responden $(30 \%)$.
B. Analisa Univariat

1. Pengetahuan

Tabel 3

\begin{tabular}{llc}
\hline Pengetahuan Tes IVA & Jumlah Responden & $\%$ \\
\hline Kurang & 17 & 57 \\
Cukup & 10 & 33 \\
Baik & 3 & 10 \\
\hline Total & 30 & 100 \\
\hline
\end{tabular}

Berdasarkan data tersebut sebagian besar responden memiliki tingkat pengetahuan kurang sebesar $17 \quad(57 \%)$ responden dibandingkan dengan yang tingkat pengetahuan baik sebesar 3 (10\%) responden

2. Upaya Pencegahan

Tabel 4

\begin{tabular}{ccc}
\hline Upaya Pencegahan & Jumlah & $\%$ \\
Kanker Leher Rahim & Responden & 7 \\
\hline Baik & 2 & 20 \\
Cukup & 6 & 73 \\
Kurang & 22 & 100 \\
\hline Total & 30 & \\
\hline
\end{tabular}


Berdasarkan data tersebut sebagian besar responden memiliki upaya kurang dalam pencegahan ca cervix sebesar $22 \quad(73 \%)$ responden dibandingkan dengan upaya pencegahan baik sebesar $2(7 \%)$ responden

C. Analisa Bivariat

Tabel 5

\begin{tabular}{|c|c|c|c|c|c|c|c|c|}
\hline \multirow{3}{*}{$\begin{array}{c}\text { Tingkat } \\
\text { Pengetahuan }\end{array}$} & \multicolumn{6}{|c|}{ Upaya Pencegahan Kanker Leher Rahim } & \multicolumn{2}{|c|}{ Total } \\
\hline & \multicolumn{2}{|c|}{ Baik } & \multicolumn{2}{|c|}{ Cukup } & \multicolumn{2}{|c|}{ Kurang } & & \\
\hline & $\mathrm{N}$ & $\%$ & $\mathrm{~N}$ & $\%$ & $\mathrm{~N}$ & $\%$ & $\mathrm{~N}$ & $\%$ \\
\hline Baik & 0 & 0 & 1 & 3,3 & 16 & 53,3 & 17 & 56,6 \\
\hline Cukup & 0 & 0 & 4 & 13,3 & 6 & 33,3 & 10 & 33,3 \\
\hline Kurang & 2 & 6,6 & 1 & 3,3 & 0 & 0 & 3 & 9,9 \\
\hline Total & 2 & 10 & 6 & 36,6 & 22 & 53,3 & 30 & 100 \\
\hline
\end{tabular}

Hasil tabulasi silang menunjukkan bahwa dari 17 responden yang memiliki pengetahuan kurang, $16(53,3 \%)$ memiliki upaya pencegahan yang kurang sedangkan $1(3,3 \%)$ responden memiliki upaya pencegahan dalam kategori cukup.

Dari 10 responden yang memiliki pengatahuan cukup, $6(33,3 \%)$ responden memiliki upaya pencegahan yang kurang dibandingkan dengan yang cukup sebesar $4(13,3 \%)$ responden.

Dari 3 responden yang memiliki pengetahuan yang baik, $1(3,3 \%)$ responden memiliki upaya pencegahan yang kurang dan $2(6,6 \%)$ memiliki upaya pencegahan yang baik. Hasil analisis statistic uji square $\mathrm{p}$ value sebesar $0,03<\mathrm{a}$ $(0,05)$. Hal ini berarti ada hubungan yang signifikan antara tingkat pengetahuan ibu tentang test IVA dengan upaya pencegahan Kanker Leher Rahim.

\section{PEMBAHASAN}

\section{A. Pengetahuan}

Pengetahuan adalah merupakan hasil "tahu" dan ini terjadi setelah orang melakukan pengindraan terhadap suatu objek tertentu. Pengindraan terjadi melalui panca indra manusia, yakni indra penglihatan, pendegaran, penciuman, rasa dan raba. Sebagian besar pengetahuan manusia diperoleh melalui mata dan telinga (Notoatmodjo, 2012).

Berdasarkan hasil penelitian di Klinik Namira Semarang diperoleh hasil sebagian besar responden berpengetahuan kurang sebanyak 17 (57) hal ini memberikan gambaran bahwa sebagian besar responden belum memiliki pengetahuan yang baik tentang test IVA. Hal ini bisa berkaitan karena latar belakang pendidikan resonden sebagian besar berpendidikan dasar dan menengah

B. Upaya Pencegahan

Menurut..Pencegahan yang utama adalah tidak berperilaku seksual yang beresiko terinfeksi HPV seperti tidak berganti-ganti pasangan seksual dan tidak melakukan hubungan seksual pada usia dini (kurang dari 18 tahun)

Menghindari faktor resiko lain yang dapat memicu terjadinya kanker seperti paparan asap rokok, menindaklanjuti hasil pemeriksaan Papsmear dan IVA jika hasil positif, dan meningkatkan daya tahan tubuh dengan mengkonsumsi makanan dengan gizi seimbang dan banyak mengandung vitamin C, A dan asam folat.

Melakukan skrining atau penapisan yang telah berusia 30-50 tahun, untuk menentukan apakah terinfeksi atau tidak dan harus ditindaklanjuti dengan pengobatan yang sesuai jika ditemukan infeksi (Shanty, 2011).

Berdasarkan hasil penelitian diperoleh hasil bahwa responden yang sering melakukan upaya pencegahan Kanker Leher Rahim yaitu sebanyak 2 (7\%) responden, untuk responden yang kadang-kadang melakukan upaya pencegahan Kanker Leher Rahim yaitu sebanyak 6 (20\%) responden, dan responden yang tidak pernah melakukan 
upaya pencegahan Kanker Leher Rahim yaitu sebanyak $22(73 \%)$ responden. Hal ini memberikan gambaran bahwa sebagian besar responden belum mengetahui tujuan upaya pencegahan Kanker Leher Rahim.

C. Analisa Tingkat Pengetahuan dengan Upaya Pencegahan

Dari penelitian ini menunjukkan bahwa terdapat responden yang berpengetahuan cukup dan baik yaitu sejumlah $(56,6 \%)$ responden, untuk kategori pengetahuan cukup sejumlah (33,3\%), sedangkan hubungan tingkat pengetahuan dengan kategori baik lebih kecil yaitu sejumlah $(9,9 \%)$ responden, dan yang melakukan upaya pencegahan dengan kategori baik lebih kecil yaitu sebanyak (10\%) responden, yang melakukan upaya pencegahan dengan kategori cukup sebanyak $(36,6 \%)$ responden, sedangkan yang melakukan upaya pencegahan dengan karegori kurang lebih banyak yaitu sebanyak $(53,3 \%)$ responden. Hasil analisis statistik uji square $\mathrm{p}$ value sebesar $0,03<\mathrm{a}$ $(0,05)$. Hal ini berarti ada hubungan yang signifikan antara tingkat pengetahuan ibu tentang test IVA dengan upaya pencegahan Kanker Leher Rahim.

Pengetahuan merupakan faktor penting dalam menentukan perilaku seseorang karena pengetahuan dapat menimbulkan perubahan persepsi dan kebiasaan masyarakat ( Notoatmodjo, 2003 )

Sehingga terdapat hubungan antara teori dan hasil penelitian karena pengetahuan berkaitan dengan upaya pencegahan Kanker Leher Rahim.

\section{SIMPULAN DAN SARAN}

Simpulan

1. Sebagian besar responden memiliki tingkat pengetahuan kurang sebesar 17 (57\%) responden

2. Sebagian besar responden memiliki upaya pencegahan yang kurang atau tidak pernah melakukan upaya pencegahan sebesar 22 (73\%) responden
3. Ada hubungan yang significan antara tingkat pengetahuan tentang IVA dan upaya pencegahan ca cervix, Dengan hasil $p$ value sebesar $0,03<\mathrm{a}(0,05)$

Saran

1. Bagi Dinas Kesehatan

Hasil penelitian ini diharapkan dapat menjadi bahan acuan dan bahan evaluasi dalam penanganan masalah pengetahuan test IVA khususnya pada PUS, sehingga penentuan arah kebijakan bagi upaya pencegahan Kanker Leher Rahim dapat dimulai dari penanganan masalah dengan melakukan pendidikan kesehatan dan penyuluhan untuk PUS.

2. Bagi Institusi Pendidikan

Hasil penelitian ini diharapkan dapat menjadi sumber studi kepustakaan sehingga dapat ikut meningkatkan pengetahuan para mahasiswi tentang materi pengetahuan IVA test dan upaya pencegahannya. Selain itu, para pembimbing dapat berpartisipasi dalam penyelesaian masalah.

3. Bagi PUS Klinik Namira Semarang

Hasil penelitian ini diharapkan dapat menjadi sumber informasi yang berharga bagi para PUS tentang pengetahuan test IVA dengan upaya pencegahan Kanker Leher Rahim, sehingga para PUS dapat mengantisipasi diri mereka dalam menyiasati pola kebiasaan sehari-hari.

4. Bagi Peneliti Lanjutan

Hasil penelitian ini diharapkan dapat menjadi tambahan wawasan dan pengetahuan peneliti yang lebih mendalam dengan variable beragam.

\section{DAFTAR PUSTAKA}

Aziz Alimul, Hidayat. 2007. Metode Penelitian dan Teknik Analisis Data Salemba Medika. Jakarta

Dinkes Kota Semarang, 2018. Profil kesehatan Kota Semarang Tahun 2018

Junuda Desby, Hadrians Kesuma.2015. Pemeriksaan Metode IVA (Inspeksi Visual Asam Asetat) untuk Pencegahan Kanker Serviks. Fakultas Kedokteran Universitas Riau. Pekan Baru

Kemenkes Kesehatan RI, 2018. Data dan Informasi Profil Kesehatan Indonesia 2018. 
https://pusdatin.kemkes.go.id/resources/ download/pusdatin/profil-kesehatanindonesia/Data-dan-Informasi_ProfilKesehatan-Indonesia-2018.pdf

Kementrian $\mathrm{RI}$, 2017. https://pusdatin.kemkes.go.id/resources/ download/pusdatin/profil-kesehatanindonesia/Profil-Kesehatan-Indonesiatahun-2017.pdf

Maharsie, dkk. 2012. Hubungan pengetahuan ibu tentang kanker serviks dengan keikutsertaan ibu melakukan IVA Test di kelurahan jebres Surakarta, diakes tanggal 7 juni 2018
Mulyati, 2015. Pengaruh Media Film Terhadap Sikap Ibu Pada Deteksi Dini Kanker Serviks https://journal.unnes.ac.id/nju/index.php /kemas/article/view/3401.

Wulandarai, Sri. 2018. Hubungan Pengetahuan Wanita Usia Subur Tentang Kanker Serviks Dengan Keikutsertaan Dalam Melakukan IVA Test Di Puskesmas Tambusai Kabupaten Rokan Hulu Tahun 2018. Maternity And Neonatal Jurnal Kebidanan.https://ejournal.upp.ac.id/index.php/akbd/article/ view/1720 